UDK 398.5:087.5

\title{
Janelle Mathis
}

University of North Texas - Department of Teacher Education \& Administration, USA janelle.mathis@unt.edu

\section{The Contemporary Lives of Age-Old Tales: Characters, Contexts, and Critical Issues}

Izvorni znanstveni rad / original research paper

Primljeno / received 20. 4. 2017. Prihvaćeno / accepted 12. 7. 2018.

DOI: $10.21066 /$ carcl.libri.8.1.5

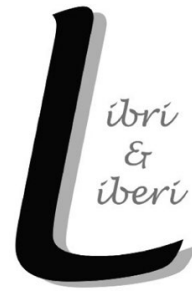

Aligned with the sociocultural nature of traditional tales and other folk literature of the Western world, this study examines three picturebooks to consider the significance of contemporary retellings of traditional tales. A critical content analysis approach to text and images employs select tenets of a particular theory for each book inclusive of childism, post-colonial, and archetype theories. The findings relate each book to current sociocultural issues: the agentic child in building community; colonial and post-colonial understandings; and identity, stereotypes, and archetypes. Additionally, environmental themes are woven through each. The findings support the ongoing significance of these living folktales for personal and community development as they connect intertextually across eras and national cultures.

Keywords: archetype, childism, content analysis, folktales, post-colonial

Traditional tales live among us not only in their earliest forms but also in contemporary retellings, mash-ups, blending, and borrowing of motifs and literary devices. Authors create intricate imagined detail around simple well-known story lines, and illustrators provide images that keep this genre alive despite changing sociocultural times. Scholars over time continue to seek meaningful literary connections to the familiar traditional tale through the lenses of revised and evolving theoretical perspectives and ideologies. Contemporary societies, interacting within changing cultural demographics and new insights into the global community, seem to seek relevance and confirmation through these familiar tales.

Drawing from the work of Jack Zipes (2012) and Bruno Bettelheim (1989) regarding the sociocultural nature of traditional tales and their potential impact on readers, this paper considers three examples of using contemporary theoretical lenses to 
explore modern retellings of the folktale genre in light of the sociocultural issues they address both blatantly and subtly. A seemingly simple text can elicit potential profound insights and response. Quoting Burkett (1979), Zipes reminds readers: "A tale becomes traditional, not by virtue of being created but by being retold and accepted. This points to interaction around the tale and yet the maintenance of its identity" (7). The critical conversations that have evolved linking the past and present within and around these tales point to their potential as an artefact for understanding sociocultural shifts from the past to present time.

As a result of extensive reading and exploration of published works that recreate a familiar Western traditional tale or that borrow literary elements to reimagine a similar context in contemporary settings, several titles were chosen that have implications for current social issues. Viewed through theoretical lenses currently used to understand and explain the literature in light of these issues, the titles are: Out of the Egg by Tina Matthews (2007); The House that Jack Built by Gavin Bishop (1999/2012); and Wolf Wanted by Ana Maria Machado and Laurent Cardon (2010). This choice is inclusive of different types of stories, forms, and characters that fall within traditional literature. The selection also represents books created within different national cultures.

The approach to this study is that of Critical Content Analysis which, in keeping with Rosenblatt's (1938) transactional theory, "reflects a hermeneutic, reader-response oriented research stance and so meaning is not in the text but in the reading event, which is a transaction between an analyst and a text" (Short 2016: 4). As with any reader, then, the text's meanings depend on the intentions of the researcher and the focus of the study at hand since the purpose of the study impacts the researcher's stance in reading as well as the interpretation of findings.

Theory is important here since it frames and points to the ways in which children's texts are caught up in wider cultural, political, and social spheres of activity. Mallan and Bradford claim (2011: 9):

Texts and theory are performative: they do something, and therefore incur important ethical responsibilities. These ethical responsibilities are not narrowly conceived in terms of moral content and values (or lack of them) advanced by texts. Rather, they are concerned with larger issues of truth, representation, and being (selfhood, identity, subjectivity).

Viewed through a critical multicultural lens in general and supported by other theoretical lenses, a critical reading of various international works resulted in variations of several sociocultural themes embedded in the retellings. Critical multicultural analysis invites readers to examine the power relations within books and the ways that books can reflect and influence representations of the world. It asks readers to scrutinise their reading for relationships of power to consider not just the stories and characters but also to conduct an analysis of the power as seen in race, class, gender, and culture (Botelho and Rudman 2009) as well as the peripheral sociopolitical and sociocultural issues. Such tenets supporting the use of critical multicultural analysis here are: the placement of agency; the assumptions of who holds power and status at the end of the text; representations of those who fall outside the dominant "norm". 
Arthur Frank (2010) is quoted by Jack Zipes as saying: "Stories work with people, for people, and always work on people, affecting what people are able to see as real, as possible and as worth doing or best avoided" (44). Frank wants to analyse how stories work by focusing on how they are in dialogue with one another, people's experiences, and societies. He draws from Bakhtin's (1994) work, as does Porter (1986) who discusses the notion of intertextuality in light of all texts being created from existing texts. Thus, this look at the ongoing life of traditional tales through their dialogue with society and the real experiences of the people therein is not a new topic but yet another example of the connections among texts across time, space, and cultures.

\section{Exploring traditional tales with a critical, contemporary eye}

Exploring the three books considered here, in light of the specific tenets of critical multicultural analysis that speak to agency, power, and the dominant norm of society, began with initial reading and rereading, giving attention to general themes that were obvious within each. Three identified themes will be discussed, a dominant theme for each book: the agentic child in building community; colonial and post-colonial understandings; and identity, stereotypes, and archetypes. Three different theoretical lenses are used to more specifically describe and understand the contemporary sociocultural theme within each of the three books.

In addition to textual content, these picturebooks require examination of the "nonlinguistic semiotic system" (Painter, Martin, and Unsworth 2014: 10). These authors of Reading Visual Narratives draw from Kress and van Leeuwen's (2006) Visual Images: The Grammar of Visual Design and the work of Halliday (1978) in using three metafunctions of a text to organise their analysis of picturebook images: ideational, interpersonal, and textual. For the purposes here, Painter, Martin, and Unsworth's various aspects of the interpersonal metafunction, primarily those referring to focalisation, character, and ambience through colour, support descriptions of the illustrations. With attention to contemporary social issues, these particular aspects of the art seem most relevant in the space limitations here to build an "affective relationship". "While it is through the mediation of speaking adults that children are introduced to the verbal voice of a picture book, it is probably the visual images that are the most significant means for setting up an affective relationship between child and book, an important step in coming to terms with the print medium" (Painter, Martin, and Unsworth 2014: 15). The discussion also draws from an outline of Kress and van Leeuwen's work by Harste (2014) in considering the placement and directionality of characters and scenes.

\section{Out of the Egg: The agentic child in building community}

Simple in text structure and in the images by Tina Matthews from New Zealand and Australia, the message in Out of the Egg is well delivered regarding notions of building relationships as seen in the efforts to create a supportive, sustaining global community. The book ends with a touch of environmental concerns, thus adding to 
its contemporary sociocultural frame. The theoretical lens of childism provides a useful additional perspective in examining the contemporary life of this particular tale. Childism speaks to how a children's book can take on a child's perspective of the world and resist the imposition of adult views. It provides insights into the ways in which children are discriminated against by adults, particularly in assumptions about children's reasoning abilities and rights and their development of agency (YoungBruehl 2012). Short (2016) discusses childism from the perspectives of YoungBruehl, Joosen (2013), Nikolajeva (2010), Nodelman (1992), and others to consider the theoretical perspectives of childism that point to the child's rights of participation. These perspectives acknowledge the child as having the ability to participate in difficult issues and understand the source of social issues, and acknowledges children for their existing identities and sense of agency. Short's focus is supportive of the children's right to be heard and their views to be considered in interactions with adults as leading to the child's development of critical consciousness to critique oppression in everyday life.

Out of the Egg retells the familiar story of the little red hen who seeks help to accomplish her daily work of planting. The story, as many readers recognise it, features a hen, often with baby chicks, who approaches animal friends for help in planting, harvesting, and preparing wheat. When the animals have excuses for not helping in each phase of the work, her response is "Then, I'll do it myself". When the time comes to enjoy the results of the work by eating the bread prepared from the wheat, she refuses to share while reminding others that she did the work, so, "I'll eat it myself". Some renditions reveal the animals as remorseful and others leave them just surprised or disappointed. The history of The Little Red Hen reveals its source in Irish or English literature that migrated to the United States around 1870 and became a picturebook decades later. According to Johnson (2016), more than sixty-five different picturebook editions, as well as other retellings in periodicals, have been published in the United States alone, providing evidence of the tale's popularity and malleability. In a comprehensive account of the literary history of this story, Johnson surveys over fifty retellings and explains the themes within the varied interpretations of authors and illustrators. She notes the following as predominant among the variants of The Little Red Hen: indolence and industry; play and work; immaturity and maturity; and class and gender conflict.

Out of the Egg reveals the little red hen seeking help in planting a green seed she has found. As she asks for assistance, she is continuously met with the familiar refrain of "Not I" to which she responds, "Then I will do it myself". In this retelling, her acquaintances are the Fat Cat, the Dirty Rat, and the Greedy Pig. Images reveal modern technology as a key reason for the hen's lack of help from others: all watch television as she asks for help in planting; all zoom off in a convertible when it is time to water; they respond negatively to her call via both phone and computer when she asks for help in weeding; and they remain toasty warm inside when she needs help sheltering the seed that is now growing into a tree (see Fig. 1). 


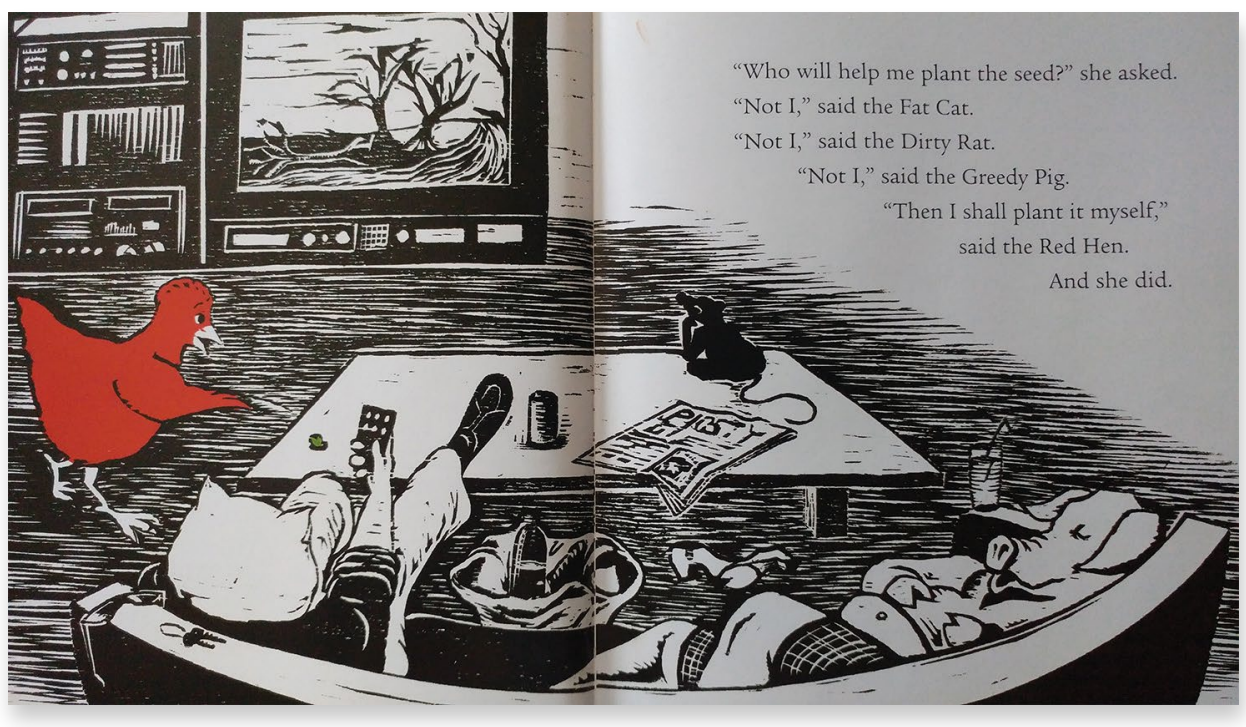

Fig. 1. A double-page spread from Out of the Egg (C) 2007 by Christina (Tina) Matthews. Permission granted by Harold Ober Associates Incorporated.

Sl. 1. Dvostranica iz Out of the Egg (C) 2007 Christina (Tina) Matthews. Objavljeno uz suglasnost Harold Ober Associates Incorporated.

Over time, the tree grows, and the red hen finds within its shelter the perfect place to lay an egg from which a single red chick is born. Eventually, little cat, little rat, and little pig walk past the fenced land with the inviting shade of the tree, and in response to their request as to who will let them in to play under the tree, the hen replies "Not I!" in keeping with the traditional tale. Immediately the little chick replies, "Mum, that's MEAN!" As the Red Hen looks at the little animals, she softly acknowledges the truth coming from her own child. In asking if she should ask them to play, the chick replied, "No, I shall ask them myself". This is in keeping with the traditional lines that in original versions spoke to the sense of agency of the red hen. The chick's perspective on this situation, perhaps without knowledge of the selfishness of the older animals years before, is given voice; however, the response of the little chick reveals the influence of mother hen's independence and work ethic as shown in her earlier interactions with cat, rat and pig. The red hen contributes to the positive message here in that she gives each of the visitors a green seed as they leave for the day. The text is as simple as earlier versions but the sociocultural message for contemporary readers adds a variety of complex topics: the need to build community by forming new relationships beyond events of the past; environmental issues that reflect on the need for all to be building our natural resources; and the role of technology as friend and foe of our global community.

Critical to contextualising this story in contemporary times are the illustrations, Japanese woodblock prints rendered in black and white. The only other colours used are red for the hen and her chick and green used for the seed, leaves of the tree, and 
eventually the grass that grows around the tree. The predominant use of black and white might seem to take away from the ambiance of the illustrations. However, the simplicity of the saturated red and green objects gives emphasis to the characters and the hen's planting efforts while also portraying the vibrancy and vitality of her work and the chick's show of a rather agentic personality. The green carries the universal colour of nature that is connected to ecology. The notion of familiarity refers to colour differentiation. If an image is restricted to one or two hues, then the image is removed from the normal everyday world since we see our surroundings through multiple colours and hues (Painter, Martin and Unsworth 2014). The use of only red and green, aside from the white and black print, is aligned with the story being that of a folktale and not part of our everyday world.

As is true of traditional literature, the story is told from a narrator's perspective, but the hen is the object of focalisation as the story is seen through her character. For example, when she first seeks help in planting the seed, the two-page spread is from the back of the friends who are focused on a television as seen in Fig. 1. On another page, as the friends ride by in their convertible, the cat who is driving looks out at the reader but with eyes shifted towards the hen who is caught up in the exhaust cloud. A food bag flies out of the car directing our attention as well to the red hen with whom the reader identifies. Throughout the story, the hen never looks directly at the reader as the focalisation is unmediated and from the perspective of the reader. However, when the chick is hatched it is looking directly at the reader as if to announce its arrival with a sense of agency from its beginning. Cityscapes beyond the place where the tree is growing are frequently pictured in the block print, indicating in black and white a larger city beyond the countryside where the animals live and in contrast with the countryside, although the infiltration of city life is seen in the actions of the Fat Cat, the Dirty Rat, and the Greedy Pig.

Within the double-page spread, after the arrival of the chick and its friends, the young animals are always positioned on the right, indicative of the "new", the future. On the last spread, the parents are sketched in black and white and on the far left, indicative of the "here and now" as the young animals exit the green area with their seeds. The book concludes with a single picture of the hen's green space with multiple trees growing in the background and a bold red hen shown in the middle, the red colour providing a visual link to the facing solid red page that speaks to her power and vibrancy. Thus, both text and images reflect the continuous placement of agency on the hen and then her chick, a tenet of critical multicultural analysis that assists in framing this story.

Community building is the clear message that evolves from taking a childism perspective in exploring this book that acknowledges the importance of the child's voice in this situation. Out of the Egg uses a traditional tale to engage readers in a contemporary theme regarding moving beyond the past, a theme of great significance as we create global citizens. Technology is considered an asset in bringing the global community together but, as shown here, it can also be instrumental in keeping us from collaborating and participating in community building. 


\section{The House that Jack Built: Understanding history as it relates to today through colonial and post-colonial insights}

In exploring this book, I found support in Zipes' discussion of memes, defined as cultural units of information such as tunes, ideas, phrases, fashion, creative arts, which are often gathered into larger units of meaning such as a story. If relevant, a meme is passed on and could become a universal meme extending beyond its culture of origin. While maintaining its roots in the oral tradition, it gathers from other stories, motifs, and, in contemporary society, is found using other modes of dissemination such as various print forms, media, photography and digital formats. Zipes discusses Drout's (2006) assertion of the need for a meme to have a "word to world fit that justifies its relevance" (Zipes 2012: 19) and that repetition and memory are crucial elements for its survival since the human can discern this recognisable pattern within many different contexts. Thus, traditional memes are created and maintained through their use within the many stories of shared experiences (Zipes). "The House that Jack Built" is a popular cumulative nursery rhyme whose origins are in the oral tradition of Great Britain. It has a rhythm and format that falls within this definition of meme as it has been a vehicle over time for the telling of many stories in many cultures. Not the least of these is the New Zealand historical account in The House that Jack Built by Gavin Bishop (1999).

The familiar rhyme and repetition of "The House that Jack Built" creates a background cadence as well as a framework for the story. The book reveals a version of the early history of New Zealand. Post-colonial theory provides tenets that address power and powerlessness, othering, and the loss of cultural identity by those colonised. These tenets are obvious as Jack, a trader, arrives from Europe in 1798 and begins a new life among those who already inhabit the land. As more settlers arrive and the Māori give up their land through trade providing farms and buildings for settlers, the spiritual god of the Māori, Papatūānuku, the earth mother, and Ranginui, the sky father, watch all the events. Change over time is uniquely described as this cumulative tale adds each new line to its telling and the illustrations capture the physical change of the land as more people, shops, and ships appear - but always with the eyes of Papatūānuku watching as portrayed in the illustrations of each page. The warm colours provide ambiance with nature's blues and greens central to each of the early pictures bordered by rust-coloured images and elaboration of text on each page. However, as the story proceeds, the shades of red become more predominant in the story and the border text says that Tümatauenga, the war god, called to the people of the land to save Mother Earth. The final image of Jack's house is one that is burned to the ground, reflective of the land wars following the failed treaty of 1840 (see Fig. 2).

The familiar repetition of the phrase "the house that Jack built" might appear to make Jack the focalising point of this story; however, the illustrations speak as well to a counter story. Prior to the last page, the characters only look at each other, giving no eye contact with the reader. This provides an unmediated focalisation, albeit a dual focalisation when viewers consider the eyes of Papatūānuku, eyes that look over the land and look to the reader. A concluding illustration shows images of both the Māori 


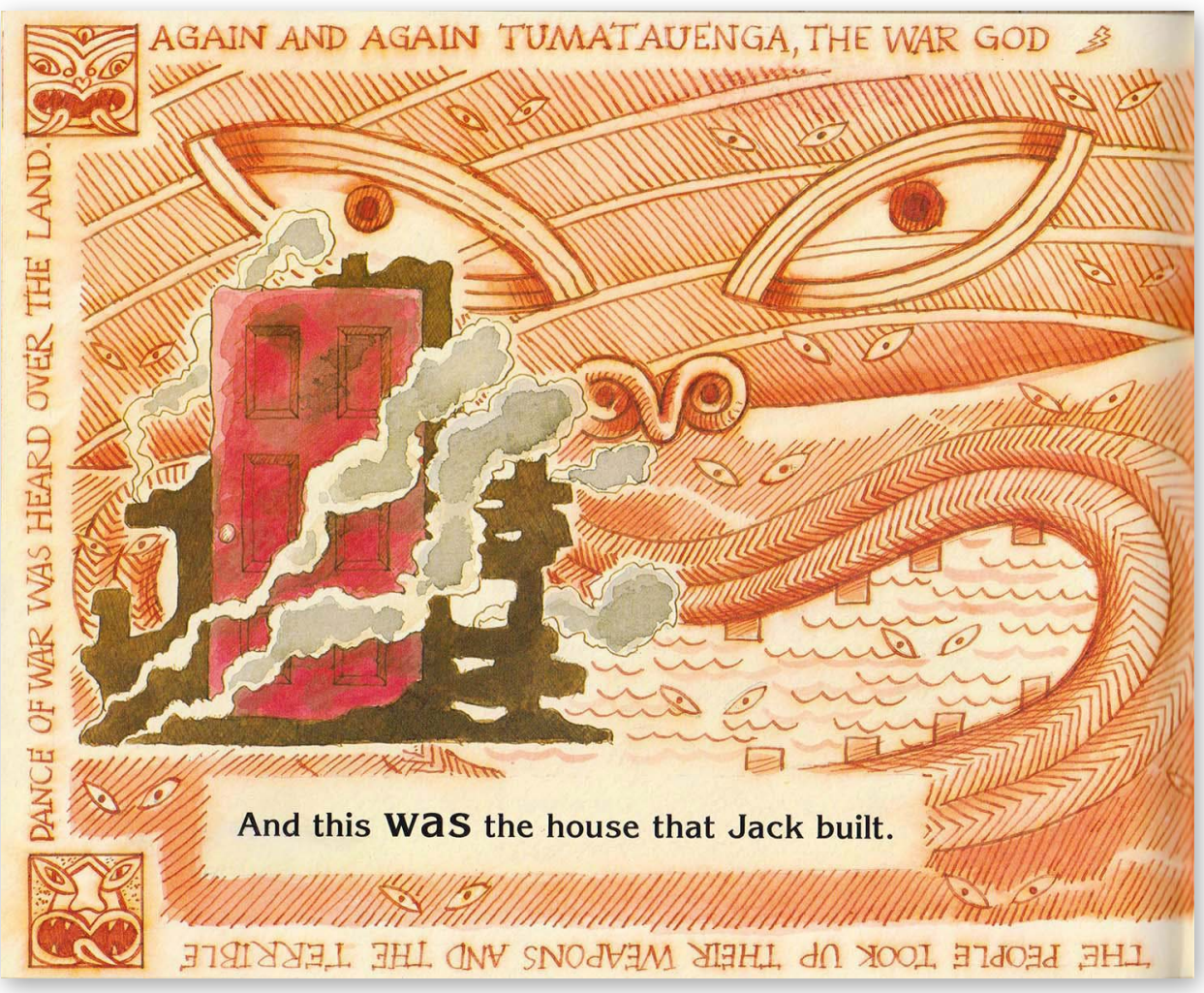

Fig. 2. An image (a page) from The House that Jack Built by Gavin Bishop. Image (C) Gavin Bishop. From The House that Jack Built, Gecko Press (2012).

Sl. 2. Slika (stranica) iz The House that Jack Built Gavina Bishopa. Autorska prava na sliku (C) Gavin Bishop. Preuzeto iz The House that Jack Built, Gecko Press (2012).

and Paketa (white man), with each figure looking straight out addressing the reader and surrounded by art from both Māori and European styles. Each is seemingly pleading his case and the reader is left to consider this perspective on New Zealand history through a post-colonial presentation - one that clarifies this concept for even younger readers.

From a post-colonial stance, this award-winning book is rich in images that show what is lost, gained, and changed as a new land is discovered and taken over by powerful explorers that colonise the inhabitants. Thus, colonial/post-colonial as a theme, as well as a theoretical perspective, emerges immediately as readers engage in text and illustrations. Among the scholars who have thoughtfully written about this book is Clare Bradford (2007) who has addressed its strength in delivering a postcolonial message around the trope of home. Through text and illustration, she discusses the symbolic representation of home as Jack begins his life in the new land with a simple house that grows over time to a larger house, a hotel, and a town. All the while the Māori are pushed aside, out of their home, but always in sight of the gods among 
whom are Papatūānuku, the earth mother, and Ranginui, the sky father. Tūmatauenga the war god, encourages the people to fight for their land. Bradford notes that the powerful image of the smouldering house at the story's end implies "that Jack's house has never properly integrated into the land and that the habitus of European life has never taken root in the colony" (Bradford 2007: 139). The last page, according to the author, Bishop, uses folk art to show the ongoing struggle between these two groups in their quest for harmony. Insights to a post-colonial theme allude to the complexity of sociocultural relations in post-colonial territories, and the viewer is left to contemplate, through the critical multicultural tenet, who holds the power.

While this is deemed a critical book for discussions with readers around the obvious theme of colonisation and taking a post-colonial perspective, it is also enriching to take a New Historicism view of this book. New Historicism states that there is no single historical account and that a history is an ongoing account of several histories that is inclusive of all people - those already included, those marginalised, and those left out. Art is considered, along with other cultural representations and social contexts, as significant in understanding any historical event. For example, the representation of the traditional spiritual world of the Māori is a critical aspect of considering the impact of the settlers on these indigenous people and the beliefs that are considered part of their cultural heritage even today. The familiar traditional rhyme and format speak to the Western traditions that were brought to New Zealand while Māori words are sprinkled throughout and images portraying the eyes of the gods and the border text give the land a voice, warning the people about what is happening. Always placed at the top of the page, the eyes reflect the ideal while the people, most frequently in the bottom half of the page, reflect the real. "The synergy of picture and text [...] provides an effective counterpoint for helping to explain the early European colonization of New Zealand through complex and multi-layered illustrations and intertextual references to the early English rhyme" (Cotton and Daly 2015: 43).

While The House that Jack Built is more the use of a familiar story frame than a retelling of the more traditional story of Jack, it provides support for the role of familiar stories, characters, and memes as structures to carry contemporary social messages.

\section{Wolf Wanted: Identity, stereotypes, and archetypes}

Needless to say, the role of the wolf in folk literature has been profoundly explored and the iconic stereotypical motif from early tales has been reborn many times over in both children's and adult literary works. Within the parameters set for this present study, over fifty recently published books were identified that reflect wolf variants. Although not all were traditional tale versions, most, with the exception of informational books, implied the traditional stereotype of the wolf. The list involved select titles from award lists in the United States.

The wolf has frequently been identified as an archetype. As acknowledged by Ghosh (2015), “[t]his animal has come to be part of our 'collective unconscious' (Jung 2010: 42), an archetype developed subliminally by society, transcending time and 
tradition" (201). With a long history of being feared and disliked due to their natural instinct to hunt other animals, often farm animals, the wolf faced extinction until the 1970s when it was declared endangered and measures were begun to save the wolf. Over literary history, the wolf can be found in idioms, aligned with its natural instincts, and games and music as well as folklore. More recently, documentaries and literature give attention to the struggles faced by wolves, their importance to the ecosystem, and the friendly nature of the lone wolf (Ghosh 2015). Citing Peter Hollindale (1999), Ghosh states that "humankind's relations with the wolf are more complex and intimate than with any other wild creature, making the wolf a robust subject for storytelling" (202). Considering Jung's statement that the wolf has influenced myths, religions, and philosophies across times and nations, it is only natural that it continues to reappear in contemporary tales.

Building on Jung's notions of the collective unconsciousness, Northrop Frye is noted for his work with archetypes, a theory of literary criticism. Frye's approach to archetype was within the role of structuralism although he acknowledged the imaginative nature of myth as a critical component. His focus was on the function of literary archetypes that according to Abrams (1993) "play an essential role in refashioning the material universe into an alternative verbal universe that is humanly intelligible and viable, because it is adapted to essential human needs and concerns" (224 - 225). Wolf stories across eras evidence both the comedic and dramatic, both docile animals and predatory animals crossing genre boundaries over time and cultures.

The considerations around archetypal mimetics here are not to analyse the various wolf images in literary format, but to consider the contemporary use of archetypes in keeping with literary archetypal criticism and theory. As each of these wolf characters has been reinvented for the purposes of this book, as well as other stories in contemporary literature, some of the basic ideas within the work of Jung and Northrop Frye can be identified as a way to acknowledge the significance of such works in understanding some contemporary sociocultural issues. Aligned with the search for identity, agency, and voice in current cultural and educational studies, the metaphorical wolf continues to thrive in children's picturebooks. Wolf Wanted is no exception in that the very framing of the book around one's identity portrayed through writing points to the use of this archetype in helping readers to make sense of their own lives and identity. According to Waude (2016), Jung said that we each have a persona, an idealised image of aspiration that reflects the identity which we wish to project to others. The various wolves depicted in Wolf Wanted reveal a personal depiction of how they perceive themselves through their application letters. At times their letters reflect the image they have been given in folk literature, while some letters present a different, often overly positive, wolf image.

Wolf Wanted written by award winning author, Ana Maria Machado, and illustrated by Laurent Cardon was published first in Brazil in 2005 and translated in 2010 into English for publication in Canada (Groundwood) by Elisa Amado. Its intertextual approach spans numerous universally known stories and is representative of the iconic wolf image that continues in all genres and across cultures and historical eras. Framed 
within a story of a rather unclear newspaper advertisement requesting a wolf, Wolf Wanted begins with a human named Manny Wolf responding to this ad only to realise that what was needed was a real wolf. The story continues with Manny Wolf accepting a position to review the applicants and various wolves applying with their identifiable credentials as realised in various folk literature - fairy tales, mythological tales, and proverbial sayings, among other forms. To each letter, Manny Wolf responds in a very professional manner as he is an avid reader and can identify the source of each wolf according to the personalities reflected in the letters (see Fig. 3). It is only after Manny Wolf has directed many applicants to other potential positions within appropriate stories that he realises what is needed is a real wolf and requests in a new advertisement information on where wolves are to be found. Thus, this modern wolf story with its intertextual connections and attention to effective letter writing takes a turn into an environmentalist story with information regarding a variety of wolves from around the world, and with Manny Wolf eventually taking on the job of photographing them.

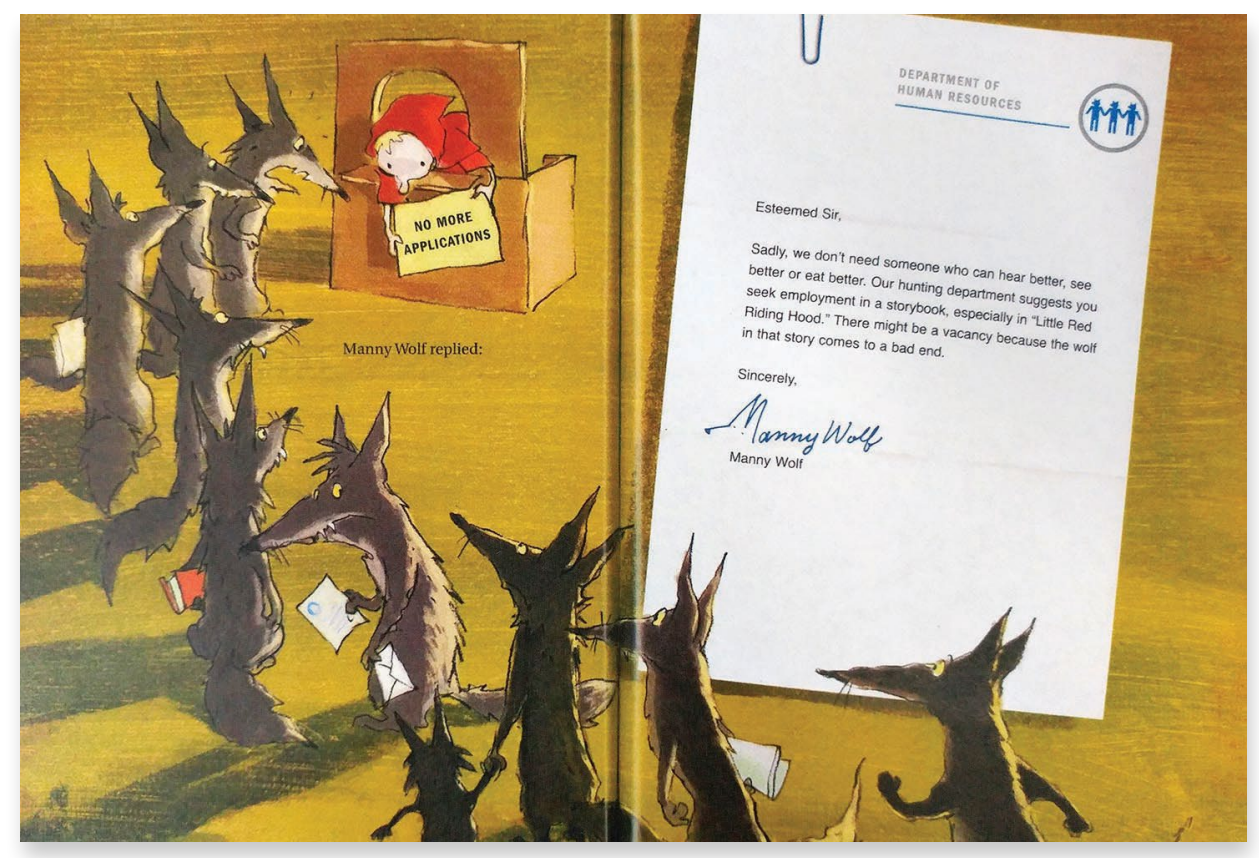

Fig. 3. A double-page spread from Wolf Wanted (2010[2005]), text copyright (C) 2004 by Ana Maria Machado, illustrations copyright (C) 2004 by Laurent Cardon, English translation copyright (C) 2010 by Elisa Amado. First published in Brazil in 2005 by Editora Atica. Reproduced with permission from Groundwood Books Ltd., Toronto. <www.groundwoodbooks.com>

Sl. 3. Dvostranica iz Wolf Wanted (2010[2005]), autorska prava za tekst (C) 2004 Ana Maria Machado, za ilustracije (C) 2004 Laurent Cardon, za engleski prijevod (C) 2010 Elisa Amado. Prvi put objavljeno u Brazilu 2005. godine u nakladi Editora Atica. Objavljeno uz suglasnost Groundwood Books Ltd., Toronto. <www.groundwoodbooks.com> 
In light of the intertextual vignettes that link the pages of Wolf Wanted, readers can potentially identify a critical multicultural text in terms of the tenets of agency, power and the dominant norm. The roles of power and domination are not always maintained from the traditional tale to this and other contemporary ones; representations of those who fall outside the dominant norm are seen through a critical multicultural lens. Additionally, readers can also identify a post-colonial perspective of othering, misconceptions, and missing voices, especially as the varied perspectives of the wolves conclude with attention given to the realistic issue of saving the wolf from endangerment and extinction.

The illustrations reveal the same wolf image throughout - sly and dark with pointed nose and ears, yellow eyes, but with varied facial expressions and body stances. Even Manny Wolf has a pointed facial profile resembling the wolves that are applying for the position. Accompanying each letter, one or more wolves are revealed in a scene that adds a twist to the traditional image brought to mind by the implied story. Each doublepage spread speaks to a different wolf from literature, but the use of the same wolf figure is a reminder that all these varied interpretations and stereotypes reference the same animal. Each illustration takes on a unique use of colour that provides ambiance suited to the story and setting portrayed and characters in contexts that mediate the reader's role in diverse ways. Such examples are: expressions of despair, as in the image of Red Riding Hood's signage saying "No More Applications"; the fierceness of the wolf who could "huff and puff"; the overpowering father wolf standing over the wolfling who refuses to apply for work because he wants to finish school; or the more gentle father wolf reading to his children with a picture of Mowgli on his wall. These are but a few of the well-constructed post-modern scenes that position traditional wolves within more contemporary social contexts. A final page shows Manny lying on the ground shooting pictures of wolves although the camera is actually aimed at a flat world map with photographs of nine varieties of wolves placed in their natural region of habitat.

Among Arthur Frank's poignant descriptions of the power of story, he includes these phrases: "The sense of self that these stories impart, the relationships constructed around shared stories, and the sense of purpose that stories both propose and foreclose" (2010: 3). The significance of Wolf Wanted can be described using these descriptors as one considers notions of identity, shared perceptions and misconceptions, and relationships and responsibility with the natural world. The multifaceted role of the wolf as archetype supports creating and articulating a viable world adapted to human needs.

\section{Concluding thoughts}

Summarising the basic premises of Arthur Frank's Stories Breathe, Zipes states: "Stories not only contribute to the making of our narrative selves but weave threads of social relationships" (4). Each of these titles reveals current perceptions of how we 
weave these relationships - how children can begin thinking about their individual and collective importance. This dialogic mode of interpretation opens our minds to perspectives through the idea that stories depend on shared narratives - so all voices can be heard. Storytellers learn to work with the stories that exist as they weave a living fabric that continues from the past into the future - a living piece of art, in Frank's words, "stories that breathe".

Bettelheim (1975) speaks of the folktale taking the child on a trip into a wondrous world; at its end, the tale reassuringly returns the child to reality and a sense of sustaining hardships and restoring the ability to master life. The hero returns to the real world better able to master life. In these contemporary lives of traditional tales, the potential for the child to realise he/she can sustain, restore, and master life situations has potential for teaching and learning global citizenship - a current topic for educators and parents today. Bettelheim also addresses the role of fantasy as the natural resources that provide raw material of personality-building: "If we are deprived of this natural resource, our life remains limited without fantasies to give us hope, we do not have the strength to meet the adversities of life. Childhood is the time when these fantasies need to be nurtured" (121). Fantasies that have sustained time, as they nurture personalities across generations, have powerful potential.

Important, but not surprising, to note is that all three books have universally recognised traditional story elements, yet each book comes from a different culture or country, inclusive of New South Wales, Australia, New Zealand, and Brazil. Ultimately, one significant point about the contemporary lives of these traditional tales is that they are lived globally in different societies and in ways that reflect ongoing issues in diverse cultures. This is a rather comprehensive statement to make around a mere three books, but it does lead readers in various cultures to consider similar stories within their own cannon and contemporary book lists. Readers are supported in the effort to identify their role and connections to others within a global society through such common traditional folklore. Additionally, all three titles carry environmental themes that create an intertextual connection across these three contemporary versions of traditional tales. Connecting young readers to the natural world and acknowledging their responsibilities to maintain and sustain it for themselves and future generations is yet another aspect of community. Such critical issues as environmentalism deserve to be situated in these traditional stories where they are understood in light of the stories of both previous and contemporary generations.

Referencing Stephens (1992), Painter, Martin, and Unsworth remind us: "Picture books, most obviously those in narrative form, constitute a significant instrument of socialisation, as a source of both overt and covert, 'ideological' messages about the world and about social values" (2014: 1). As various forms of traditional literature continue to take on the issues of the day and help readers make sense of the occurrences around us, they offer common threads of strength for weaving into these tapestries relationships with others and with the physical world in which all exist. These tapestries reflect the simplicity of childhood but, viewed either purposely or tacitly through contemporary 
theoretical stances, they provide illustrated detail for bringing together the past and present in seeking harmonious relationships. Just as Zipes addressed the significance of the Fairy Tale, so might these closely related traditional tales be regarded as (2012: 20):

$[\ldots]$ not created or intended for children. Yet they resonate with them, and children recall them as they grow to confront the injustices and contradictions of so-called real worlds. We cannot explain why the originals $[. .$.$] are so inexplicable and elusive. But$ we can elucidate why they continue to be irresistible and breathe memetically through us, offering hope that we can change ourselves while changing the world.

\section{Acknowledgments}

We are grateful to the following copyright holders for giving Janelle Mathis permission to include images from these publications in her paper in both printed and electronic versions of this issue of Libri \& Liberi: Tina Matthews and Harold Ober Associates Incorporated (New York, USA) for a double-page spread from Out of the Egg; Gecko Press (Wellington, New Zealand) for an image from The House that Jack Built by Gavin Bishop; and Ana Maria Machado, Laurent Cardon, Elisa Amado, and Groundwood Books Ltd. (Toronto, Canada) for a double-page spread from Wolf Wanted.

\section{References}

\section{Primary sources}

Bishop, Gavin. 1999. The House that Jack Built. Wellington, New Zealand: Gecko Press. Machado, Ana Maria \& Laurent Cardon. 2010 [2005]. Wolf Wanted. Transl. Elisa Amado. Toronto: Groundwood.

Matthews, Tina. 2007. Out of the Egg. New York: Houghton Mifflin Harcourt.

\section{Secondary sources}

Abrams, Meyer Howard. 1993. Archetypal Criticism. A Glossary of Literary Terms, 223225. Fort Worth: Harcourt Brace Jovanovich.

Bakhtin, Mikhail. 1994. The Bakhtin Reader: Selected Writings of Bakhtin, Medvedev, and Voloshinov, edited by Pam Morris. London: E. Arnold.

Bettelheim, Bruno. 1989. The Uses of Enchantment: The Meaning and Importance of Fairy Tales. New York: Random House.

Botelho, Maria José \& Masha Kabakow Rudman. 2009. Critical Multicultural Analysis of Children's Literature. New York: Routledge.

Bradford, Clare. 2007. Unsettling Narratives, Postcolonial Readings of Children's Literature. Ontario, Canada: Wilfrid Laurier University Press.

Burkert, Walter. 1979. Structure and History in Greek Mythology and Ritual. Berkeley: University of California Press.

Cotton, Penni \& Nicola Daly. 2015. Cross-Continental Readings of Visual Narratives: An Analysis of Six Books in the New Zealand Picture Book Collection. Bookbird: A Journal of International Children's Literature 53 (2): 37-44.

Drout, Michael. 2006. How Tradition Works: A Meme-based Cultural Poetics of the AngloSaxon Tenth Century. Tempe: Arizona Center for Medieval and Renaissance Studies.

Frank, Arthur. 2010. Letting Stories Breathe: A Socio-Narratology. Chicago: University of Chicago Press. 
Frye, Northrop. 2001. The Archetypes of Literature. In The Norton Anthology: Theory and Criticism, edited by Vincent B. Leitch, 1445-1457. New York: Norton.

Ghosh, Kerenza. 2015. Who's Afraid of the Big Bad Wolf? Children's Responses to the Portrayal of Wolves in Picturebooks. In Challenging and Controversial Picturebooks, Creative and Critical Responses to Visual Texts, edited by Janet Evans, 201-224. London: Routledge.

Halliday, Michael A.K. 1978. Language as Social Semiotic. London: Arnold.

Harste, Jerome. 2014. The Art of Learning to Be Critically Literate. Language Arts 92 (2): 90-102.

Hollindale, Peter. 1999. Why the Wolves Are Running. The Lion and the Unicorn 23 (1): 97-115.

Johnson, Deidre A. 2016. Why No One Helps the Little Red Hen: Picture Book Interpretations of a Folktale. In Children's and Young Adult Literature and Culture: A Mosaic of Criticism, edited by Amie A. Doughty, 7-30. Newcastle upon Tyne: Cambridge Scholars Publishing.

Joosen, Vanessa. 2013. The Adult as Foe or Friend: Childism in Guus Kuijer's Criticism and Fiction. International Research in Children's Literature 6 (2): 205-217.

Jung, Carl \& Stanley M. Dell (translator). 1939. The Integration of the Personality. New York: Farrar and Rinehart.

Kress, Gunther \& Theo van Leeuwen. 2006. Reading Images: The Grammar of Visual Design. London: Routledge.

Mallan, Kerry \& Clare Bradford. 2011. Introduction: Bringing Back Theory. In Contemporary Children's Literature and Film: Engaging with Theory, edited by Kerry Mallan and Clare Bradford, 1-11. New York: Palgrave Macmillan.

Nikolajeva, Maria. 2010. Power, Voice, and Subjectivity in Literature for Young Readers. New York: Routledge.

Nodelman, Perry. 1992. The Other: Orientalism, Colonialism, and Children's Literature. Children's Literature Association Quarterly 17 (10): 29-35.

Painter, Clare, J.R. Martin \& Len Unsworth. 2014. Reading Visual Narratives: Image Analysis of Children's Picture Books. Sheffield, UK: Equinox.

Porter, James E. 1986. Intertextuality and the Discourse Community. Rhetoric Review 5 (1): 34-47.

Rosenblatt, Louise. 1938. Literature as Exploration. New York: D. Appleton-Century.

Short, Kathy. 2016. Critical Content Analysis as a Research Methodology. In Critical Content Analysis of Children's and Young Adult Literature: Reframing Perspective, edited by Holly Johnson, Janelle Mathis, and Kathy Short, 1-15. New York: Routledge.

Short, Kathy. 2016. The Right to Participate. In Critical Content Analysis of Children's and Young Adult Literature: Reframing Perspective, edited by Holly Johnson, Janelle Mathis, and Kathy Short, 137-154. New York: Routledge.

Stephens, John.1992. Language and Ideology in Children's Fiction. Harlow, UK and New York: Longman.

Waude, Adam. 2016. Carl Jung: Archetypes and Analytical Psychology. Psychologist World.

$<$ https://www.psychologistworld.com/cognitive/carl-jung-analytical-psychology> (accessed 1 March 2018).

Young-Bruehl, Elisabeth. 2012. Childism: Confronting Prejudice against Children. New Haven, CT: Yale University Press.

Zipes, Jack. 2012. The Irresistible Fairy Tale: The Cultural and Social History of a Genre. Princeton, NJ: Princeton University Press. 


\section{Janelle Mathis}

Odsjek za obrazovanje učitelja, Sveučilište North Texas, SAD

\section{Suvremeni život drevnih priča: likovi, konteksti i kritička pitanja}

Uz društvenokulturnu narav tradicionalnih priča i drugih oblika folklorne književnosti zapadnoga svijeta, ovaj rad istražuje tri slikovnice te razmatra suvremene inačice drevnih priča. Tekstu i slikama pristupa se kritičkom analizom sadržaja te se upotrebljavaju odabrane perspektive određenih teorija u raščlambi pojedinih naslova, uključujući teoriju djecizma (childism), postkolonijalnu i arhetipsku teoriju. Rezultati povezuju svaku analiziranu knjigu sa suvremenom sociokulturnom tematikom, tj. temom djelatnoga djeteta u uspostavljanju zajednice, kolonijalnoga i postkolonijalnoga razumijevanja, kao i identiteta, stereotipa i arhetipa. Osim toga, u svim se analizama provlači i tematika okoliša. Utvrđuje se trajna važnost živih folklornih priča za osobni razvoj i razvoj zajednice jer one intertekstualno povezuju različita razdoblja i nacionalne kulture.

Ključne riječi: arhetip, djecizam, analiza sadržaja, folklorne priče, postkolonijalno 